УДК 619:612.017:579.62:636.2

(C) 2012

Киричко Б. П., доктор ветеринарних наук,

Скрипка М. В., доктор ветеринарних наук, професор,

Киричко О. Б., кандидат ветеринарних наук

Полтавська державна аграрна академія

\title{
ДИНАМІКА ОПСОНО-ФАГОЦИТАРНОЇ РЕАКЦІЇ ОРГАНІЗМУ КОРІВ ЗА ЗАСТОСУВАННЯ ЕКОЛОГІЧНО ЧИСТОГО РОЗЧИНУ ПОЛТАВСЬКОГО БІШОФІТУ
}

\section{Рецензент - доктор ветеринарних наук А. А. Замазій}

\begin{abstract}
Наведені результати досліджень динаміки опсонофагоичттарної реакиії організму здорових та хворих на субклінічний мастит корів за зовнішнього застосування екологічно чистого розчину полтавського бімофіту з різними інтервалами. Бімофіт $\epsilon$ екологічно чистою сумішию солей - сухим залишком вод колишнього Пермського моря. Надзвичайно важливою для резистентності організму є опсоно-фагоцитарна реакція. Дослідженням встановлено підвищення фагоцитарної активності нейтрофілів, зростання фагоцитарного індексу та фагоиитарного числа. Найефективнішим, за показниками опсоно-фагоиитарної реакції, було застосування розчину полтавського бішофіту з інтервалами 12 та 24 години.
\end{abstract}

Ключові слова: бішофіт, мастит, корови, фагоичити.

Постановка проблеми. Аграрна галузь, зокрема тваринництво та ветеринарна медицина, мають неабияку потребу в природних екологічно чистих засобах. Одним із таких $є$ полтавський бішофіт. Він уже знайшов своє використання у різних галузях гуманної та ветеринарної медицини, проте його вплив на організм тварин залишається недостатньо вивченим.

Аналіз основних досліджень і публікацій, у яких започатковано розв'язання проблеми. Розчин полтавського бішофіту (РПБ) - справжнє джерело мінеральних речовин. Він $є$ екологічно чистою сумішшю солей - сухим залишком вод колишнього Пермського моря, що утворився близько 270 млн років тому на глибині 25002700 метрів. Звідти його добувають у вигляді розчину із загальною мінералізацією 350-450 г/л, у якій переважають солі магнію, натрію, калію, кальцію, крім того міститься понад 30 мікроелементів (мідь, марганець, залізо тощо) [1].

Відомо, що $з$ метою підвищення рівня неспецифічних факторів захисту частіше всього застосовують макро- та мікроелементи, що вводять до раціону годівлі $[2,3]$.
Численні дослідження показують, що фактори неспецифічного захисту організму реагують першими й зниження їх рівня може призвести до захворювання і загибелі тварин. Надзвичайно важливою для резистентності організму $\epsilon$ опсонофагоцитарна реакція. Фагоцити периферійної крові мають хемотаксичну чутливість, амебоподібну рухливість та здатність захоплювати й перетравлювати генетично чужорідний матеріал. Фагоцитоз посилюють опсоніни, комплемент (фракція $\mathrm{C}_{3}$ ), адреналін, гістамін, пірогени, солі кальцію і магнію, соматотропний гормон гіпофізу [4-7].

Метою нашого дослідження було вивчення впливу розчину полтавського бішофіту на динаміку опсоно-фагоцитарної реакції організму корів.

Матеріали і методи досліджень. Дослідження проводили на здорових та хворих на субклінічний мастит, стрептококової й стафілококової етіології, коровах, із яких (за принципом аналогів) сформували дев’ять груп по 6-10 корів у кожній. Корови перших семи груп були хворими на субклінічний мастит. Тваринам першої-четвертої груп втирали розчин полтавського бішофіту в шкіру вим'я переважно ураженої запаленням частки впродовж 5-7 хвилин відразу після доїння 3 інтервалами 12, 24, 48 та 60 годин - до зникнення ознак захворювання. Для корів п'ятої групи застосовували препарат на його основі - санобіт, за такою ж схемою, як і розчин полтавського бішофіту, інтервалом у 24 години. У шостій групі корів лікували традиційним методом, шляхом застосування внутрім'язево стрептоміцину сульфату та бензилпеніциліну натрієву сіль у загальноприйнятих дозах двічі на добу протягом 5-7 діб, до одужання. Попередньо визначали чутливість до них виділених із зразків молока бактерій. У восьму і дев'яту групи ввійшли здорові корови. Тваринам восьмої групи розчин полтавського бішофіту втирали за вищевказаною методикою 3 інтервалом у 24 години. Корови сьомої та дев' ятої груп були контрольними.

За всіма тваринами було встановлено постійне 


\section{ВЕТЕРИНАРНА МЕДИЦИНА}

клінічне спостереження. До застосування розчину полтавського бішофіту та протягом 28-ми діб після цього кожні 7 діб відбирали зразки молока для бактеріологічних досліджень і зразки крові для вивчення динаміки опсоно-фагоцитарної реакції.

Результати досліджень. Бактеріологічні до- слідження молока показали, що субклінічний мастит у корів мав стрептококову та стафілококову етіологію. Результати дослідження опсонофагоцитарної реакції організму здорових і хворих на субклінічний мастит корів наведені в таблиці.

\section{Динаміка опсоно-фагоцитарної реакції організму корів за застосування розчину}

полтавського бішофіму

\begin{tabular}{|c|c|c|c|}
\hline Групи тварин & $\Phi A, \%$ & ФЧ, од & ФІ, од \\
\hline \multicolumn{4}{|c|}{ до застосування препаратів } \\
\hline 1 & $46,00 \pm 1,06$ & $6,59 \pm 0,31$ & $3,02 \pm 0,12$ \\
\hline 2 & $45,70 \pm 0,87$ & $6,39 \pm 0,27$ & $2,91 \pm 0,13$ \\
\hline 3 & $45,83 \pm 0,71$ & $6,62 \pm 0,25$ & $3,03 \pm 0,07$ \\
\hline 4 & $45,50 \pm 0,89$ & $6,79 \pm 0,39$ & $3,09 \pm 0,17$ \\
\hline 5 & $46,67 \pm 1,48$ & $6,17 \pm 0,48$ & $2,86 \pm 0,18$ \\
\hline 6 & $46,50 \pm 1,42$ & $6,28 \pm 0,40$ & $2,92 \pm 0,20$ \\
\hline 7 & $46,17 \pm 1,06$ & $6,59 \pm 0,33$ & $3,05 \pm 0,23$ \\
\hline 8 & $49,50 \pm 1,19$ & $7,08 \pm 0,52$ & $3,46 \pm 0,16$ \\
\hline 9 & $49,17 \pm 1,24$ & $7,02 \pm 0,56$ & $3,44 \pm 0,26$ \\
\hline \multicolumn{4}{|c|}{ через 7 діб застосування препаратів } \\
\hline 1 & $58,67 \pm 1,06^{* * *}$ & $9,27 \pm 0,60 * *$ & $5,42 \pm 0,27 * * *$ \\
\hline 2 & $57,90 \pm 1,30 * * *$ & $9,07 \pm 0,37 * * *$ & $5,25 \pm 0,29 * * *$ \\
\hline 3 & $49,83 \pm 0,53$ & $7,35 \pm 0,48$ & $3,67 \pm 0,30$ \\
\hline 4 & $46,00 \pm 1,06$ & $7,02 \pm 0,23$ & $3,23 \pm 0,10$ \\
\hline 5 & $58,50 \pm 1,95 * * *$ & $9,38 \pm 0,64 * * *$ & $5,50 \pm 0,45 * * *$ \\
\hline 6 & $47,17 \pm 1,06$ & $6,31 \pm 0,39$ & $2,98 \pm 0,22$ \\
\hline 7 & $46,00 \pm 0,89$ & $6,52 \pm 0,23$ & $3,00 \pm 0,14$ \\
\hline 8 & $60,40 \pm 1,06 * * *$ & $9,17 \pm 0,41 * * *$ & $5,55 \pm 0,30 * * *$ \\
\hline 9 & $49,50 \pm 0,89$ & $7,11 \pm 0,54$ & $3,51 \pm 0,19$ \\
\hline \multicolumn{4}{|c|}{ через 14 діб після початку застосування препаратів } \\
\hline 1 & $59,17 \pm 1,06^{* * *}$ & $9,49 \pm 0,50 * *$ & $5,60 \pm 0,20 * * *$ \\
\hline 2 & $58,20 \pm 1,08 * * *$ & $9,30 \pm 0,44 * * *$ & $5,41 \pm 0,27 * * *$ \\
\hline 3 & $50,17 \pm 0,36$ & $7,56 \pm 0,44$ & $3,79 \pm 0,35$ \\
\hline 4 & $46,17 \pm 1,06$ & $7,13 \pm 0,20$ & $3,29 \pm 0,14$ \\
\hline 5 & $58,67 \pm 1,60 * * *$ & $9,57 \pm 0,56^{* *}$ & $5,63 \pm 0,41 * * *$ \\
\hline 6 & $47,33 \pm 1,24$ & $6,41 \pm 0,34$ & $3,04 \pm 0,18$ \\
\hline 7 & $46,33 \pm 1,24$ & $6,72 \pm 0,30$ & $3,13 \pm 0,20$ \\
\hline 8 & $60,80 \pm 0,94 * * *$ & $9,35 \pm 0,42 * *$ & $5,69 \pm 0,28 * * *$ \\
\hline 9 & $49,50 \pm 1,60$ & $7,14 \pm 0,54$ & $3,52 \pm 0,26$ \\
\hline \multicolumn{4}{|c|}{ через 21 добу застосування препаратів } \\
\hline 1 & $59,17 \pm 0,53 * * *$ & $9,72 \pm 0,47 * *$ & $5,75 \pm 0,22 * * *$ \\
\hline 2 & $58,50 \pm 0,97 * * *$ & $9,45 \pm 0,42 * *$ & $5,61 \pm 0,26 * * *$ \\
\hline 3 & $50,33 \pm 0,71$ & $7,80 \pm 0,48$ & $3,93 \pm 0,30$ \\
\hline 4 & $46,50 \pm 1,24$ & $7,22 \pm 0,21$ & $3,35 \pm 0,13$ \\
\hline 5 & $58,83 \pm 1,42 * * *$ & $9,73 \pm 0,48^{* *}$ & $5,75, \pm 0,36 * * *$ \\
\hline 6 & $47,64 \pm 1,06$ & $6,52 \pm 0,40$ & $2,74 \pm 0,22$ \\
\hline 7 & $46,50 \pm 0,89$ & $6,70 \pm 0,31$ & $3,13 \pm 0,21$ \\
\hline 8 & $61,10 \pm 0,65 * * *$ & $9,42 \pm 0,40 * *$ & $5,75 \pm 0,21 * * *$ \\
\hline 9 & $49,33 \pm 0,87$ & $7,06 \pm 0,42$ & $3,49 \pm 0,23$ \\
\hline
\end{tabular}

Примітка: $* * *-p<0,001 ; * *-p<0,01 ; *-p<0,05$, у порівнянні 3 контрольними здоровими тваринами 
У ході дослідження опсоно-фагоцитарної реакції встановлено, що у хворих тварин спостерігається зниження фагоцитарної активності нейтрофілів у порівнянні зі здоровими тваринами на $6,8 \%$, фагоцитарного числа - на $5,2 \%$ i фагоцитарного індексу - на 13,6 \%.

Після лікування тварин РПБ і санобітом рівень показників опсоно-фагоцитарної реакції підвищується. На сьому добу після початку дослідження у групі тварин, яким застосовували РПБ з інтервалом 12 годин, фагоцитарна активність нейтрофілів вірогідно збільшується (на 21,6 \%). Різниця 3 контрольними групами була вірогідною й склала зі здоровими тваринами $15,6 \%(\mathrm{p}<0,001)$, із хворими тваринами - 21,6\% ( $<0,001)$, із тваринами, яких лікували антибіотиками, $-19,6 \%$ (p<0,001). Фагоцитарне число у цієї групи також вірогідно підвищується (на 28,8 \%). Різниця з контрольними групами була вірогідною й становила зі здоровими тваринами $23,3 \%(\mathrm{p}<0,01)$, із хворими коровами - 29,7\% (p<0,01), коровами, яких лікували антибіотиками, $-31,9$ \% (p< 0,01). Фагоцитарний індекс підвищувався на 44,3\%. Різниця 3 контрольними групами була вірогідною й складала зі здоровими тваринами - 35,2\% $(\mathrm{p}<0,001)$, із хворими коровами - $44,7 \%$ $(\mathrm{p}<0,001)$ та 3 коровами, яких лікували антибіотиками, $-45 \%(\mathrm{p}<0,001)$.

У групі корів, яких лікували РПБ з інтервалом 24 години, фагоцитарна активність підвищується на $21,1 \%$. Різниця 3 контрольними групами була вірогідною й складала зі здоровими тваринами $14,5 \%(\mathrm{p}<0,01)$, із хворими тваринами $-20,6 \%$ $(\mathrm{p}<0,001)$, з тваринами, яких лікували антибіотиками, $-18,5 \%(\mathrm{p}<0,001)$.

Фагоцитарне число вірогідно збільшується (на 29,5 \%). Різниця 3 тваринами контрольних груп була також вірогідною й становила зі здоровими тваринами $21,6 \%(\mathrm{p}<0,01)$, із хворими коровами - 28,1\% ( $<0,001)$, із коровами, яких лікували антибіотиками, $-30,4 \%(\mathrm{p}<0,001)$. Фагоцитарний індекс зростає в групі на 44,6 \%. Різниця 3 тваринами контрольних груп була також вірогідною й становила зі здоровими тваринами $33,1 \% \quad(\mathrm{p}<0,001)$, із контролем-2 - $42,9 \%$ $(\mathrm{p}<0,001)$, із контролем-3 - 43,2\% $(\mathrm{p}<0,001)$.

У групі тварин, яким РПБ застосовували 3 інтервалом 48 годин, фагоцитарна активність нейтрофілів збільшувалася на 8,0 \% і наблизилася до рівня показника у контрольних здорових тварин. Різниця з хворими тваринами була вірогідна й становила $7,7 \%(\mathrm{p}<0,01)$, із тваринами, яких лікували антибіотиками, $-5,3$ \% $(\mathrm{p}<0,05)$. Фаго- цитарне число збільшилося, але невірогідно (на 9,9\%), наближаючись до рівня показника у здорових тварин і навіть був вищим на 3,3\%. Різниця 3 хворими тваринами становила 11,3\% ( $>0,05)$, хворими тваринами, яких лікували антибіотиками, $-14,2 \%$ (p>0,05). Фагоцитарний індекс у тварин групи не вірогідно збільшувався (на $17,4 \%$ ). Різниця 3 контрольними групами була не вірогідною й становила із здоровими тваринами $4,4 \%$, із хворими коровами $-18,3 \%$, із тими, яких лікували антибіотиками, $-18,8 \%$.

У групі тварин, яким застосовували РПБ $з$ інтервалом у 60 годин, фагоцитарноа активність нейтрофілів залишається на попередньому рівні, а фагоцитарне число та фагоцитарний індекс мають незначне підвищення. Фагоцитарне число зростає на $3,3 \%$; його рівень залишається нижчим, ніж у здорових тварин, на $1,3 \%$, хворих корів і корів, яких лікували антибіотиками, відповідно, на 7,2 \% і 10,1 \%. Фагоцитарний індекс підвищувався на 4,3\%. Він був нижчим, ніж у здорових тварин, на 7,9 \% і вищим у хворих корів і корів, яких лікували антибіотиками, на 7,1 \% і 7,7 \% відповідно.

У корів, яких лікували санобітом, рівень фагоцитарної активності нейтрофілів вірогідно збільшувався (на 20,2 \%). Різниця з тваринами контрольних груп була вірогідною й становила зі здоровими тваринами $15,4 \%(\mathrm{p}<0,01)$, із хворими коровами - $21,4 \%(\mathrm{p}<0,001)$, із коровами, яких лікували антибіотиками, $-18,5 \%$ ( $<0,001)$. Фагоцитарне число у групі вірогідно збільшується (на $34,2 \%$ ). Різниця з тваринами контрольних груп була вірогідною й становила зі здоровими тваринами $24,2 \%(\mathrm{p}<0,01)$, із хворими коровами $30,5 \%(\mathrm{p}<0,01)$, із коровами, яких лікували антибіотиками, $-32,7 \%$ ( $<<0,01)$. Фагоцитарний індекс вірогідно підвищувався (на 48,0%). Різниця 3 тваринами контрольних груп була вірогідною й складала зі здоровими тваринами $36,2 \%$ $(\mathrm{p}<0,01)$, із хворими $-45,5 \%(\mathrm{p}<0,001)$, із коровами, яких лікували антибіотиками, - 45,8 \% $(\mathrm{p}<0,001)$.

У здорових тварин, яким застосовували РПБ, рівень опсоно-фагоцитарної реакції вірогідно підвищувався. Фагоцитарна активність нейтрофілів збільшувалася на 18,1%. Різниця 3 контрольними здоровими тваринами була вірогідною й становила $18,1 \%(\mathrm{p}<0,001)$. Фагоцитарне число зростало 3 $7,08 \pm 0,52$ од. до $9,17 \pm 0,41$ од. (p<0,001). Фагоцитарний індекс підвищувався на $37,7 \%$. Різниця 3 контрольними здоровими тваринами була вірогідною й становило $36,8 \%(\mathrm{p}<0,001)$. 


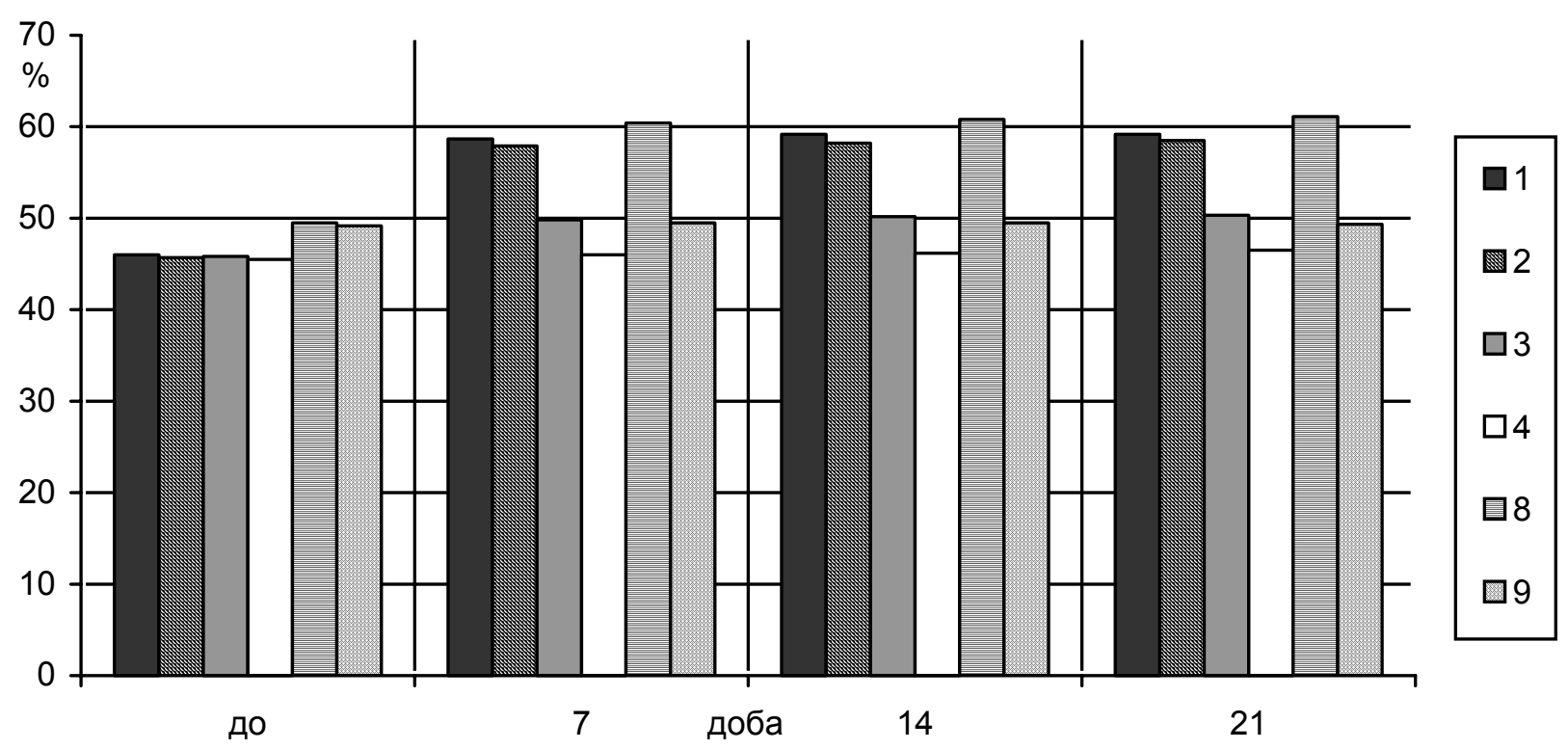

\section{Рис. Динаміка фагоцитарної активності нейтрофілів за застосування РПБ із різними інтервалами}

В інших групах показники підтримувалися на попередньому рівні. Така тенденція опсонофагоцитарної реакції збереглася до кінця досліду. Динаміка фагоцитарної активності нейтрофілів показана на рисунку.

\section{БІБЛІОГРАФІЯ}

1. Бердник В. П. Проблеми та завдання ветеринарної медицини / Бердник В. П. // Вісник Полтавського державного сільськогосподарського інституту. - 1998. - № 1. - С. 31-34.

2. Булгаков $A$. B. Влияние комплекса солей микроэлементов и витаминов на некоторые показатели обмена веществ и резистентность бычков на откорме / Булгаков А. В., Каврус М. А., Клетицкий М. Т. // Ветеринарная наука - производству. - 1989. C. $136-140$.

3. Вишняков С. И. Обмен микроэлементов у сельскохозяйственных животных / Вишняков С. И. М. : Колос, 1967. - 256 с.
Висновок. У здорових та хворих на субклінічний мастит корів спостерігали вірогідне збільшення опсоно-фагоцитарної реакції організму корів після застосування розчину полтавського бішофіту з інтервалом 12-24 години.

4. Демченко А. В. Ветеринарна мікробіологія та імунологія / Демченко А. В., Бортничук В. О., Скибіцький В. Г. [та ін.]. - К. : Урожай, 1996. $368 \mathrm{c}$.

5. Петров Р. В. Иммунология / Петров Р. В. М. : Медицина, 1987. - 414 с.

6. Резникова Л. С. Комплемент и его значение в иммунологических реакциях / Резникова Л. С. М. : Медицина, 1967. - 271 с.

7. Prisler M. T. Clucocortioid reseptor dovn - regulation in neutrophils of periparturient cows / Prisler M. T., Weber P.S.D., Tempelman R. J. et. al. // Am. J. Veter. Res. - 2000. - Vol. 61, № 1. - P. 14-19. 